\title{
Statistical Control Charts: Performances of Short Term Stock Trading in Croatia
}

\author{
Ksenija Dumičić \\ Faculty of Economics and Business, University of Zagreb, Croatia \\ Berislav Žmuk \\ Faculty of Economics and Business, University of Zagreb, Croatia
}

\section{Abstract}

Background: The stock exchange, as a regulated financial market, in modern economies reflects their economic development level. The stock market indicates the mood of investors in the development of a country and is an important ingredient for growth. Objectives: This paper aims to introduce an additional statistical tool used to support the decision-making process in stock trading, and it investigate the usage of statistical process control (SPC) methods into the stock trading process. Methods/Approach: The individual (I), exponentially weighted moving average (EWMA) and cumulative sum (CUSUM) control charts were used for gaining trade signals. The open and the average prices of CROBEX 10 index stocks on the Zagreb Stock Exchange were used in the analysis. The statistical control charts capabilities for stock trading in the short-run were analysed. Results: The statistical control chart analysis pointed out too many signals to buy or sell stocks. Most of them are considered as false alarms. So, the statistical control charts showed to be not so much useful in stock trading or in a portfolio analysis. Conclusions: The presence of non-normality and autocorellation has great impact on statistical control charts performances. It is assumed that if these two problems are solved, the use of statistical control charts in a portfolio analysis could be greatly improved.

Keywords: investments; statistical process control; exponentially weighted moving average (EWMA) control chart, cumulative sum (CUSUM) control chart

JEL classification: C22, C79, D53, G1 1

Paper type: Research article

Received: $20^{\text {th }}$ December, 2015

Accepted: 10 $10^{\text {th }}$ March, 2015

Citation: Dumičić, K., Žmuk, B. (2015). "Statistical Control Charts: Performances of Short Term Stock Trading in Croatia", Business Systems Research, Vol. 6, No.1, pp. 2235.

DOI: $10.1515 / \mathrm{bsrj}-2015-0002$

\section{Introduction}

The stock market could be observed as a vital part of a country's economy, finances and growth. Tachiwou (2010) observes the stock market as an indicator of an 
economy's financial health. He showed that the stock market development positively affects economic growth in the short run and in the long run. Among factors that explain the high relevance of stock markets Manas (2005) emphasizes their effects on consumption and investments. Based on a sample of seven countries Caporale et al. (2004) have concluded that a well-developed stock market has a significant impact on economic growth in the long run, faster capital accumulation and better resource allocation.

Consequently, it is obvious that the stock market, in addition to its effect on economy, has an impact on inhabitants' welfare. In order to try to increase the impact of the stock market on their welfare, individuals can take the role of investors and be included in stock trading. In order to participate on the stock market, individuals need to be financially literate (van Rooij et al., 2011). Almenberg et al. (2012) showed that men participate on the stock market more than women because of their higher financial literacy and higher risk aversion. Another problem which has to be addressed because it leads to lower stock market participation of individuals is their perception of the trustworthiness of the stock market. Guiso et al. (2008) think that better financial education about the stock market would reduce the lack of trust in stock markets. Hong et al. (2004) came to the conclusion that households (individuals) that interact with their neighbours or that attend church are more likely to participate on the stock market. The development of the Internet reduced the impact of certain causes of low stock market participation such as transaction costs, information costs and limited access (Bogan, 2008).

The main research question is whether statistical control charts could also be used in trading stocks, i.e. Whether control charts are capable of giving signals for buying, holding and selling stocks. Also, it is unknown whether an investor can beat the market and achieve better financial results than other investors by using control charts.

McNeese et al. (2002) pointed out that the major reason why managers do not use control charts to monitor financial data is the lack of needed information. Also, managers consider that control charts are inappropriate for their kind of work. Because of that in their decision-making process they are oriented only on financial reports. Although control charts are not used in financial data analysis in practice, some researchers have tried to apply them in different portfolio analyses. So, in order to detect changes in the performance of a credit portfolio, Gandy (2012) used a wide range of different versions of cumulative sum (CUSUM) control charts. However, Rebisz (2014) admits that control charts were rarely explored as a technique in portfolio analysis. Consequently, the following research goal is defined:

RG 1: Research goal of the paper is to investigate if statistical control charts could be a quality basis for making decisions about trading on the stock market.

In order to inspect research goal, prices of stocks from the CROBEX10 market index from the Zagreb Stock Exchange are observed. Two parallel analyses are conducted in the paper. In the first analysis open prices and in the second analysis average prices are used. In both analyses the focus is on the analysis based on individual (I), exponentially weighted moving average (EWMA) and cumulative sum (CUSUM) control charts.

\section{Data and Methodology}

The Zagreb Stock Exchange (ZSE) as the modern central place of securities trading in the Republic of Croatia was established in 1991 (Zagreb Stock Exchange, 2014b). After merging the Varaždin Stock Exchange (VSE) to ZSE in 2007, ZSE became the only regulated stock exchange in Croatia (Benić et al., 2008). In 2013, there were 368 
active traded securities out of which 208 were listed stocks (Zagreb Stock Exchange, 2014a). In September 2013, there were overall 9 stock (equity) indices on ZSE: CROBEX; CROBEX 10; CROBEXindustrija; CROBEXkonstrukt; CROBEXnutris; CROBEXplus; CROBEXtr; CROBEXtransport; CROBEXturist (Zagreb Stock Exchange, 2014d). Each index includes a different stock portfolio according to the stocks sector, free float market capitalization and/or turnover.

In order to have enough data points, or trading days, needed for the analysis, the stocks which are going to be observed should have high free float market capitalization and a trade tradition. To ensure fulfilment of these requirements, the shares from the CROBEX 10 index are observed.

Table 1

CROBEX10 Index Stock Members on 1 September 2014 and the Number of Trading Days in 2012

\begin{tabular}{|l|l|l|}
\hline Stock symbol & Enterprise & Total number of trading days in $\mathbf{2 0 1 2}$ \\
\hline ADPL-R-A & AD Plastik d.d. & 248 \\
\hline ADRS-P-A & Adris grupa d.d. & 240 \\
\hline ATGR-R-A & Atlantic Grupa d.d. & 245 \\
\hline ERNT-R-A & Ericsson Nikola Tesla d.d. & 250 \\
\hline HT-R-A & Hrvatski Telekom d.d. & 250 \\
\hline INA-R-A & INA-industrija nafte d.d. & 246 \\
\hline KORF-R-A & Valamar Adria Holding d.d. & 250 \\
\hline LEDO-R-A & Ledo d.d. & 237 \\
\hline PODR-R-A & Podravka d.d. & 247 \\
\hline PTKM-R-A & Petrokemija d.d. & 249 \\
\hline
\end{tabular}

Source: Zagreb Stock Exchange (2014C)

The CROBEX 10 index includes 10 stocks, which are shown in Table 1. These stocks are ten top CROBEX index shares based on free float market capitalization and turnover (Zagreb Stock Exchange, 2014c). Because the CROBEX index includes 25 stocks which have more than 90\% trading days (Zagreb Stock Exchange, 2014c), both requirements are fulfilled.

Selected stocks are observed from 1 January to 31 December 2012. The data from this period will show control charts capabilities for stock trading in the short run. According to Table 1, stocks ERNT-R-A, HT-R-A and KORF-R-A had most trading days (250 trading days) in that period. On the other hand, the stock LEDO-R-A had 237 trading days in that period, which is the fewest number of days among the observed stocks.

On its web page, ZSE gives different historical data about stock trading. The data variables given for each stock are: trading date; open price; highest price; lowest price; last price; average price; price change in \%; number of trades on a certain trading date; trading volume; and total turnover on a certain trading date. It has to be emphasized that all the variables are important in a portfolio analysis, but after their careful review, it has been concluded that there are two variables an investor could be most interested in. The selected variables are the open price and the average price. Both variables are given in Croatian kuna (HRK).

It has to be emphasized that here the investor's main goal is not to earn by holding stocks but it is to earn on the difference between buy and sell prices. Because of that no additional payments or other investors' rights, which they earn during the period of holding the stock, such as dividends, are considered in the analyses. 
There are a lot of different statistical control charts which can be used in the analyses (Montgomery et al., 2011b. Montogmery, 2013). In the analyses only one variable, the open price or the average price, is observed. Consequently, the univariate control charts could be used in the analyses. Furthermore, both observed variables are numeric continuous and they can take only positive values. According to that, only control charts for variables would be appropriate for use in the analyses. Because of that the following control charts are used: control chart for individual units (I), moving range (MR) control chart, exponentially weighted moving average (EWMA) control chart and cumulative sum (CUSUM) control chart. The MR control chart cannot take negative values. Because of that it could be hard to recognize buy and sell signals. Consequently, the MR control chart was not observed in detail as the other mentioned control charts.

The control charts for individual units $(I)$ are used when no rational subgroups can be created or when the observed samples are all of size $n=1$ (Liv et al., 2011). That is true for the observed situation because only one open price and one average price are available for each trading day. The general model for a control chart includes determining the centre line (CL), the upper control limit (UCL), and the lower control limit $(L C L)$. If $W$ is the sample statistics of a quality characteristic of interest, then $C L$, $U C L$ and $L C L$ are in general given by:

$$
\begin{aligned}
U C L_{W} & =\mu_{W}+k \cdot \sigma_{W} \\
C L_{W} & =\mu_{W} \\
L C L_{W} & =\mu_{W}-k \cdot \sigma_{W}
\end{aligned}
$$

where $\mu_{W}$ is the mean of $W, k$ is the distance from the CL expressed in standard deviation units, $\sigma_{W}$ is the standard deviation of $W$ (Montgomery et al., 2011a). In most cases values 2 or 3 are used as the $k$ value, (Dumičić et al., 2011a). That is why these two values have been used in the analyses.

The centre line and the control limits for the I control chart can alternatively be calculated as:

$$
\begin{aligned}
U C L_{I} & =\mu_{I}+k / d_{2} \cdot \overline{M R} \\
C L_{I} & =\mu_{I} \\
L C L_{I} & =\mu_{I}-k / d_{2} \cdot \overline{M R}
\end{aligned}
$$

where $\mu_{I}$ is the mean of individual data points, $k$ is the distance from the $C L$ expressed in standard deviation units, where $d_{2}$ is tabulated Shewhart's factor, $\overline{M R}$ is the mean of moving range. In the process of calculating moving range only two values are always used. In case $n=2$, Shewhart's factor $d_{2}$ is 1.128 . Therefore, if $k=2$ then $k / d_{2}=1.77$, and if $k=3$ then $k / d_{2}=2.66$ (Wild et al., 1999). If the control limits are calculated in that alternative way, the MR control chart can be observed as a support to the I control chart.

The exponentially weighted moving average control chart, which was introduced by Roberts (1959), is used when the observed data points are not independent, they are positively autocorrelated and the process mean is not constant because it is changing slowly (Montgomery et al., 1989). So, the EWMA control chart is 
appropriate for detecting small shifts in the process mean (Dumičić et al., $2011 \mathrm{~b}$ ). The centre line and the control limits for the EWMA control chart are given by:

$$
\begin{aligned}
\mathrm{UCL}_{\text {EWMA }} & =\mu_{E W M A}+k(\hat{\sigma} / \sqrt{n}) \sqrt{\frac{\lambda}{2-\lambda}\left[1-(1-\lambda)^{2 t}\right]} \\
\mathrm{CL}_{\mathrm{EWMA}} & =\mu_{E W M A} \\
\mathrm{LCL}_{\mathrm{EWMA}} & =\mu_{E W M A}-k(\hat{\sigma} / \sqrt{n}) \sqrt{\frac{\lambda}{2-\lambda}\left[1-(1-\lambda)^{2 t}\right]}
\end{aligned}
$$

where $\mu_{E W M A}$ is the mean of the observed variable; $k$ is the distance from the $C L$ expressed in standard deviation units; $\hat{\sigma} / \sqrt{n}$ is the standard deviation of the observed variable where $\hat{\sigma}$ is the sample standard deviation and $n$ is the sample size; $\sqrt{\frac{\lambda}{2-\lambda}\left[1-(1-\lambda)^{2 t}\right]}$ is the factor of correction which includes the weight parameter $(\lambda)$ and the time $(t)$. The weight parameter is given by interval $0<\lambda<1$. If $\lambda$ approaches 0 , more weight is given to the earliest averages (del Castillo, 2002). The cumulative sum (CUSUM) control chart was introduced by Page (1954) and it is based on the cumulative sums. The same as the EWMA control chart, the CUSUM control chart can detect a relatively small shift in the process mean very quickly (Ryu et al., 2010). The centre line and the control limits for the CUSUM control chart are given by:

$$
\begin{aligned}
\mathrm{UCL}_{\text {CUSUM }} & =\mu_{\text {CUSUM }}+k(\hat{\sigma} / \sqrt{n}) \\
\mathrm{CL}_{\text {CUSUM }} & =\mu_{\text {CUSUM }} \\
\mathrm{LCL}_{\text {CUSUM }} & =\mu_{\text {CUSUM }}-k(\hat{\sigma} / \sqrt{n})
\end{aligned}
$$

where $\mu_{\text {CUSUM }}$ is the mean of the cumulative sums; $k$ is the distance from the $C L$ expressed in standard deviation units; $\hat{\sigma} / \sqrt{n}$ is the standard deviation of the observed variable where $\hat{\sigma}$ is the sample standard deviation and $n$ is the sample size (SAS Institute, 2014). In order to calculate data points for the CUSUM control chart from original values their mean is subtracted. In the following step, these differences are summed in order to create the cumulative sum (Riaz et al., 2011). If the process operates at random without drift, it can be expected that values above and values under the mean would cancel out. Therefore, the cumulative sum should result in the score of 0 . On the other hand, if the cumulative value consistently rises or falls, that suggests the presence of a trend (Montogomery et al., 2011 a).

\section{Short-run Stock Trading Analysis}

The short-run analysis implies that data from a short period are observed. Depending on the research field the definition of what is considered a short period can be very different. In this paper a short period is defined as the period of one year. Consequently, the data from the period from 1 January to 31 December 2012 has been used in the analyses. First, the analyses based on the open prices of CROBEX 10 stocks were conducted. Afterwards, the average prices of CROBEX 10 stocks were analysed. 
The explorative analysis has shown a large difference of open price values among different stocks in the CROBEX 10 index. So, KORF-R-A with the value of HRK 70.61 had the lowest open price in 2012. On the other side, LEDO with the value of HRK 7,720.00 had the highest open price in 2012. Table 2 reveals that LEDO-R-A had the highest average open price value, whereas KORF-R-A had the lowest. Coefficients of variation are considerably low for all ten observed stocks, which resulted in the medians being very close to the means. PTKM-R-A had the highest coefficient of variation in 2012 (13.60\%).

Table 2

Explorative Analysis of Open Prices of CROBEX10 Stocks in HRK in 2012

\begin{tabular}{|l|l|l|l|l|l|l|l|}
\hline Share & $\mathbf{k}$ & Min. & Max. & Mean & Median & $\begin{array}{l}\text { Std. } \\
\text { dev. }\end{array}$ & $\begin{array}{l}\text { Var. coef. } \\
\text { (in \%) }\end{array}$ \\
\hline ADPL-R-A & 248 & 100.99 & 128.94 & 111.52 & 108.73 & 7.42 & 6.66 \\
\hline ADRS-P-A & 240 & 202.01 & 256.98 & 222.67 & 217.00 & 13.29 & 5.97 \\
\hline ATGR-R-A & 245 & 454.00 & 550.00 & 492.05 & 492.02 & 19.77 & 4.02 \\
\hline ERNT-R-A & 250 & 880.01 & $1,374.99$ & $1,158.10$ & $1,175.05$ & 109.64 & 9.47 \\
\hline HT-R-A & 250 & 193.00 & 244.40 & 211.00 & 205.99 & 13.89 & 6.58 \\
\hline INA-R-A & 246 & $3,550.00$ & $4,500.00$ & $3,858.21$ & $3,728.02$ & 265.83 & 6.89 \\
\hline KORF-R-A & 250 & 70.61 & 110.99 & 94.30 & 95.57 & 11.58 & 12.28 \\
\hline LEDO-R-A & 237 & $4,900.00$ & $7,720.00$ & $5,836.94$ & $5,701.04$ & 660.84 & 11.32 \\
\hline PODR-R-A & 247 & 206.01 & 276.50 & 239.94 & 242.99 & 19.73 & 8.22 \\
\hline PTKM-R-A & 249 & 184.80 & 340.00 & 229.27 & 226.73 & 31.17 & 13.60 \\
\hline
\end{tabular}

Source: Author's calculations

In order to conduct an outlier analysis, first all open prices of CROBEX10 stocks were standardized ant then box plots were construct. The box plots of open prices of CROBEX 10 stocks based on standardized values from 2012 are shown in Figure 1.

According to Figure 1 there could be some outlier open prices at five observed CROBEX10 stocks. If as an outlier is considered an open price that deviates more than three standard deviations from the mean open price, then it is obvious that outliers are present only at PTKM-R-A stock. It has to be emphasized that these outliers are not specially treated or omitted from the further analysis because each data point is valuable for an investor in the process of decision making.

The correlation of open prices of CROBEX 10 stocks based on Pearson correlation coefficient is given in Table 3. According to the data only ADRS-P-A and LEDO-R-A have statistically significant correlation at significance level of $5 \%$. The correlation between these two stocks is positive (0.757) what indicates that there is a tendency of the same direction change of the stocks' price. In other words, if one stock price is rising there is high probability that the second stock price would rise also. The correlation analysis is very important in portfolio analysis because it helps to determine certain level of risk and keep it on desirable level. 
Figure 1

Box Plots of Open Prices of CROBEX10 Stocks, Standardized Valves, 2012

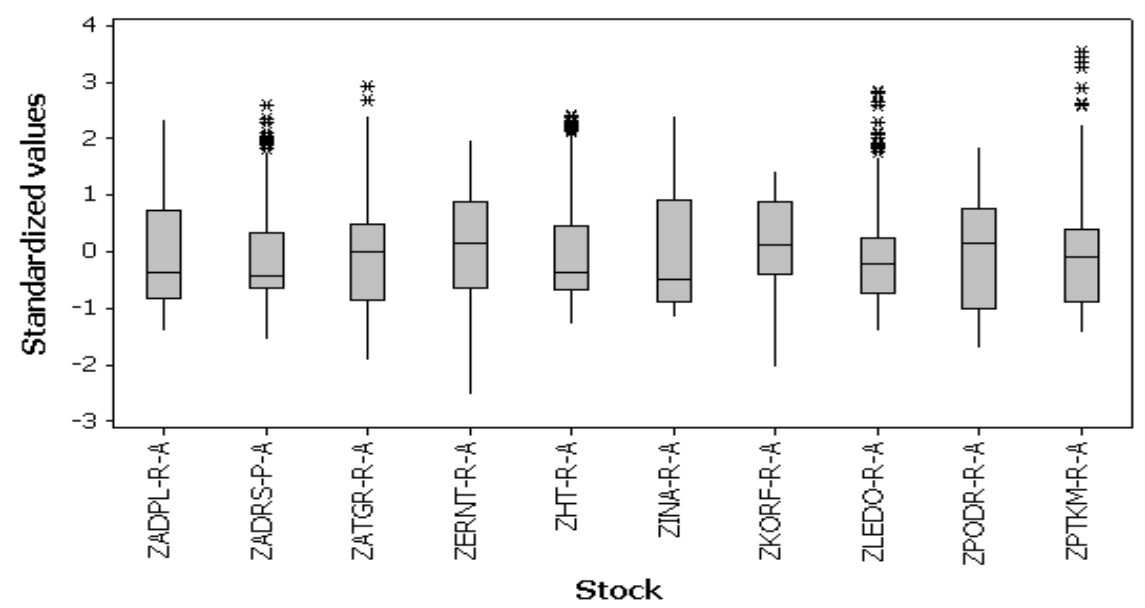

Source: Author's illustration

Table 3

Correlation Analysis of Open Prices of CROBEX10 Stocks, Pearson Correlation Coefficient, 2012

\begin{tabular}{|c|c|c|c|c|c|c|c|c|c|c|c|}
\hline & & ADPL & ADRS & ATGR & ERNT & HT & INA & KORF & LEDO & PODR & PTKM \\
\hline \multirow{3}{*}{ ADPL } & Pearson Corr. & 1 & $-.541^{* *}$ & .088 & -.026 & -.007 & $-.709^{* *}$ & -.074 & $-.149^{*}$ & -.051 & $.654^{* *}$ \\
\hline & Sig. (2-tailed) & & .000 & .172 & .689 & .912 & .000 & .244 & .022 & .428 & .000 \\
\hline & $\mathrm{N}$ & 248 & 240 & 245 & 248 & 248 & 246 & 248 & 237 & 247 & 248 \\
\hline \multirow{3}{*}{ ADRS } & Pearson Corr. & $-.541^{* *}$ & 1 & $.529^{* *}$ & $.604^{* *}$ & $-.195^{* *}$ & $.713^{* *}$ & $.612^{* *}$ & $.757^{* *}$ & $.570^{* *}$ & $-.312^{* *}$ \\
\hline & Sig. (2-tailed) & .000 & & .000 & .000 & .002 & .000 & .000 & .000 & .000 & .000 \\
\hline & $\mathrm{N}$ & 240 & 240 & 240 & 240 & 240 & 240 & 240 & 237 & 240 & 240 \\
\hline \multirow{3}{*}{ ATGR } & Pearson Corr. & .088 & $.529^{* *}$ & 1 & $.627^{* *}$ & -.065 & .008 & $.399^{* *}$ & $.678^{* *}$ & $.628^{* *}$ & -.023 \\
\hline & Sig. (2-tail) & .172 & .000 & & .000 & .311 & .899 & .000 & .000 & .000 & .723 \\
\hline & $\mathrm{N}$ & 245 & 240 & 245 & 245 & 245 & 245 & 245 & 237 & 245 & 245 \\
\hline \multirow{3}{*}{ ERNT } & Pearson Corr. & -.026 & $.604^{* *}$ & $.627^{* *}$ & 1 & .123 & $.303^{* *}$ & $.417^{* *}$ & $.688^{* *}$ & $.719^{* *}$ & -.113 \\
\hline & Sig. (2-tailed) & .689 & .000 & .000 & & .053 & .000 & .000 & .000 & .000 & .076 \\
\hline & $\mathrm{N}$ & 248 & 240 & 245 & 250 & 250 & 246 & 250 & 237 & 247 & 249 \\
\hline \multirow{3}{*}{ HT } & Pearson Corr. & -.007 & $-.195^{* *}$ & -.065 & .123 & 1 & $-.309^{* *}$ & $-.713^{* *}$ & $-.215^{* *}$ & $.334^{* *}$ & $-.332^{* *}$ \\
\hline & Sig. (2-tailed) & .912 & .002 & .311 & .053 & & .000 & .000 & .001 & .000 & .000 \\
\hline & $\mathrm{N}$ & 248 & 240 & 245 & 250 & 250 & 246 & 250 & 237 & 247 & 249 \\
\hline \multirow{3}{*}{ INA } & Pearson Corr. & $-.709^{* *}$ & $.713^{* *}$ & .008 & $.303^{* *}$ & $-.309^{* *}$ & 1 & $.515^{* *}$ & $.526^{* *}$ & $.253^{* *}$ & $-.406^{* *}$ \\
\hline & Sig. (2-tailed) & .000 & .000 & .899 & .000 & .000 & & .000 & .000 & .000 & .000 \\
\hline & $\mathrm{N}$ & 246 & 240 & 245 & 246 & 246 & 246 & 246 & 237 & 246 & 246 \\
\hline \multirow{3}{*}{ KORF } & Pearson Corr. & -.074 & $.612^{* *}$ & $.399^{* *}$ & $.417^{* *}$ & $-.713^{* *}$ & $.515^{* *}$ & 1 & $.673^{* *}$ & $.175^{* *}$ & $.349^{* *}$ \\
\hline & Sig. (2-tailed) & .244 & .000 & .000 & .000 & .000 & .000 & & .000 & .006 & .000 \\
\hline & $\mathrm{N}$ & 248 & 240 & 245 & 250 & 250 & 246 & 250 & 237 & 247 & 249 \\
\hline \multirow{3}{*}{ LEDO } & Pearson Corr. & $-.149^{*}$ & $.757^{* *}$ & $.678^{* *}$ & $.688^{* *}$ & $-.215^{* *}$ & $.526^{* *}$ & $.673^{* *}$ & 1 & $.716^{* *}$ & $-.139^{*}$ \\
\hline & Sig. (2-tailed) & .022 & .000 & .000 & .000 & .001 & .000 & .000 & & .000 & .032 \\
\hline & $\mathrm{N}$ & 237 & 237 & 237 & 237 & 237 & 237 & 237 & 237 & 237 & 237 \\
\hline \multirow{3}{*}{ PODR } & Pearson Corr. & -.051 & $.570^{* *}$ & $.628^{* *}$ & $.719^{* *}$ & $.334^{* *}$ & $.253^{* *}$ & $.175^{* *}$ & $.716^{* *}$ & 1 & $-.349^{* *}$ \\
\hline & Sig. (2-tailed) & .428 & .000 & .000 & .000 & .000 & .000 & .006 & .000 & & .000 \\
\hline & $\mathrm{N}$ & 247 & 240 & 245 & 247 & 247 & 246 & 247 & 237 & 247 & 247 \\
\hline \multirow{3}{*}{ PTKM } & Pearson Corr. & $.654^{* *}$ & $-.312^{* *}$ & -.023 & -.113 & $-.332^{* *}$ & $-.406^{* *}$ & $.349^{* *}$ & $-.139^{*}$ & $-.349^{* *}$ & 1 \\
\hline & Sig. (2-tailed) & .000 & .000 & .723 & .076 & .000 & .000 & .000 & .032 & .000 & \\
\hline & $\mathrm{N}$ & 248 & 240 & 245 & 249 & 249 & 246 & 249 & 237 & 247 & 249 \\
\hline
\end{tabular}

Note: ${ }^{* *}$ - correlation significant at the 0.01 (2-tailed), * 0.05

Source: author's calculations 
After a brief explorative analysis, CROBEX10 stocks open prices were analysed using selected control charts. The constructed selected control charts for PODR-R-A only are given in Figure 2. It has to be emphasized that the value of 0.30 was used as the weight or nonstationarity parameter $(\lambda)$ at the EWMA control chart. This value was selected as a compromise between the reaction to change and the impact of previous values. If $\lambda$ is close to 1 , the reaction to change is high but the impact of previous values is negligible. On the other hand, the smaller value of $\lambda$ results in a higher impact of previous values but the reaction to change is slower (Box et al., 2009). Hunter (1986) suggested selecting the value of $\lambda$ close to 0.20 as a good compromise for EWMA charting. Because a slightly stronger emphasis was to be given to the reaction to change, the chosen value was $\lambda=0.30$, which is slightly higher than the recommended value.

Figure 2

Control Charts of PODR-R-A Stocks Open Prices Given in HRK in 2012, $k=247$ : (a) Control Chart for Individual Units (I); (b) Moving Range (MR) Control Chart; (c) Exponentially Weighted Moving Average (EWMA) Control Chart $(\lambda=0.3)$; (d) Cumulative Sum (CUSUM) Control Chart

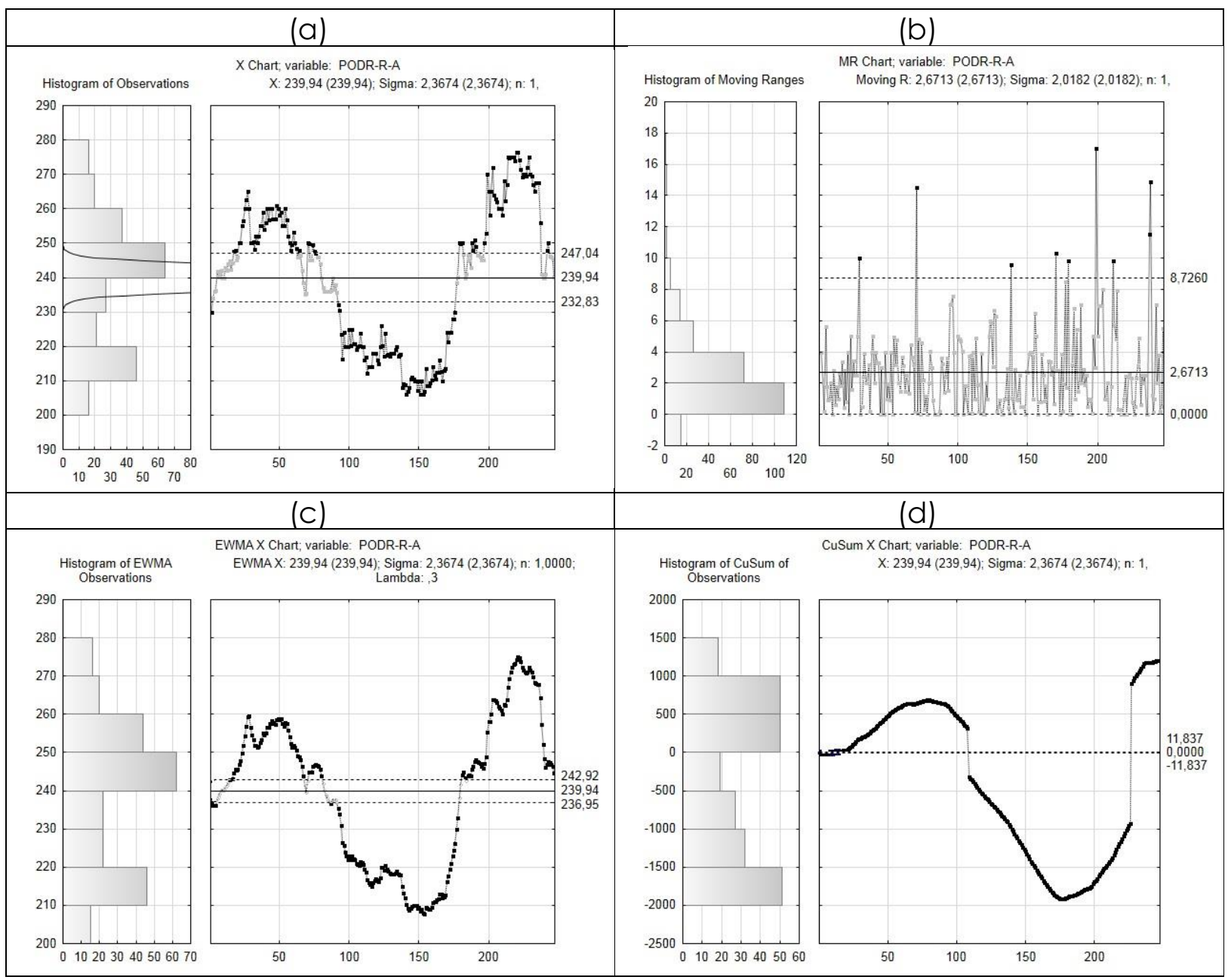

Source: Author's illustration

The I, MR, EWMA and CUSUM control charts were made for all CROBEX10 stocks, but the control charts only for PODR-R-A are presented in Figure 2. Figure 2 reveals 
that there are too many dots outside control limits suggesting that most of the time the process is out of statistical control. These dots outside control limits should be signs to investors for performing an action - to buy or to sell stocks. But it is obvious that there are too many of them and it is likely that most of them are giving false alarms. These false alarms are in connection with the error Type I, i.e. making a conclusion that the observed process is not under statistical control while in reality it is (Chen, 2010). This problem is present not only at PODR-R-A, but at all other CROBEX10 stocks also. Consequently, it is hard to undertake some reasonable financial actions meaning that stock open prices in combination with statistical control chart cannot be used in a portfolio analysis.

Table 4

Explorative Analysis of Average Prices of CROBEX10 Stocks in HRK in 2012

\begin{tabular}{|l|l|l|l|l|l|l|l|}
\hline Stock & $\mathbf{k}$ & Min. & Max. & Mean & Median & $\begin{array}{l}\text { Std. } \\
\text { dev. }\end{array}$ & $\begin{array}{l}\text { Var. coef. } \\
\text { (in \%) }\end{array}$ \\
\hline ADPL-R-A & 248 & 101.02 & 128.35 & 111.46 & 108.50 & 7.38 & 6.62 \\
\hline ADRS-P-A & 240 & 203.37 & 253.57 & 222.71 & 216.50 & 13.32 & 5.98 \\
\hline ATGR-R-A & 245 & 456.23 & 548.01 & 492.37 & 493.15 & 20.45 & 4.15 \\
\hline ERNT-R-A & 250 & 880.09 & $1,378.76$ & $1,159.19$ & $1,175.19$ & 109.83 & 9.47 \\
\hline HT-R-A & 250 & 193.64 & 243.76 & 210.89 & 205.92 & 13.83 & 6.56 \\
\hline INA-R-A & 246 & $3,550.00$ & $4,499.37$ & $3,867.06$ & $3,747.93$ & 266.97 & 6.90 \\
\hline KORF-R-A & 250 & 71.00 & 110.85 & 94.33 & 95.36 & 11.51 & 12.20 \\
\hline LEDO-R-A & 237 & $4,947.40$ & 7.839 .72 & $5,849.52$ & $5,748.19$ & 664.09 & 11.35 \\
\hline PODR-R-A & 247 & 205.17 & 276.53 & 240.21 & 244.05 & 19.78 & 8.24 \\
\hline PTKM-R-A & 249 & 185.07 & 354.87 & 228.98 & 226.46 & 31.21 & 13.63 \\
\hline
\end{tabular}

Source: Author's calculations

In Figure 3 are given box plots of average prices of CROBEX 10 stocks based on standardized data values from 2012. The box plots revealed possibility of outlier presence at five stocks (ADRS-P-A, ATGR-R-A, HT-R-A, LEDO-R-A, PTKM-R-A) but only PTKM-R-A had them. So there were three stock prices were distant more than three standard deviations from the average price of PTKM-R-A in 2012. Again, any additional procedure to deal with the outliers was not undertaken.

Figure 3

Box Plots of Average Prices of CROBEX10 Stocks, Standardized Valves, 2012

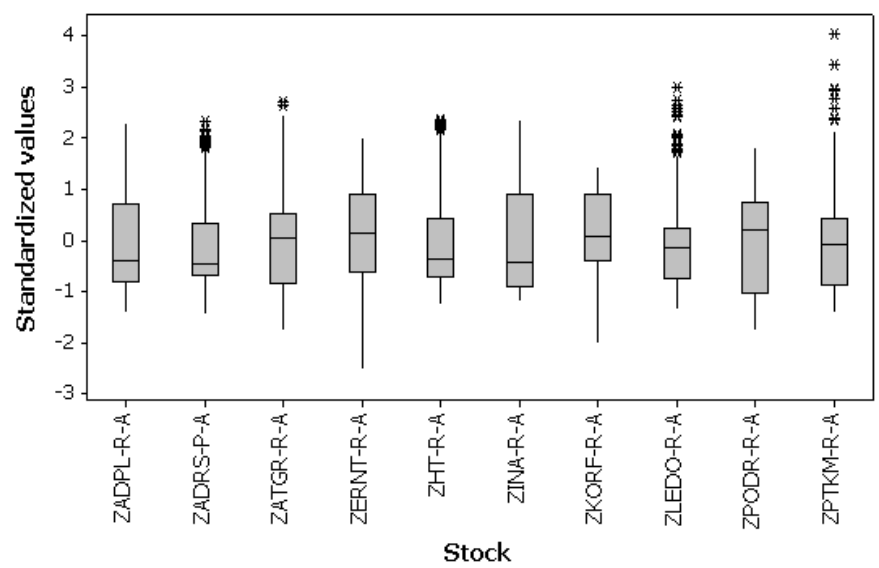

Source: Author's illustration

An explorative analysis of CROBEX 10 stocks average prices showed that, in 2012, KORF-R-A had the lowest average price which amounted to HRK 71.00 whereas 
LEDO-R-A had the highest average price which amounted to HRK 7,839.72. In spite of huge differences between different CROBEX 10 stocks, the average price variation is rather low for each observed stock. The low level average stock price variations are singled out by coefficients of variations which are considerably lower than $30 \%$ for all the stocks. Basic results of the explorative analysis of CROBEX10 stocks average prices in 2012 are given in Table 4.

Table 5

Correlation Analysis of Average Prices of CROBEX10 Stocks, Pearson Correlation Coefficient, 2012

\begin{tabular}{|c|c|c|c|c|c|c|c|c|c|c|c|}
\hline & & ADPL & ADRS & ATGR & ERNT & HT & INA & KORF & LEDO & PODR & PTKM \\
\hline \multirow{3}{*}{ ADPL } & Pearson Corr. & 1 & $-.549 * *$ & .091 & -.030 & -.005 & $-.717^{* *}$ & -.088 & $-.155^{*}$ & -.054 & $.632 * *$ \\
\hline & Sig. (2-tailed) & & .000 & .156 & .637 & .940 & .000 & .165 & .017 & .402 & .000 \\
\hline & $\mathrm{N}$ & 248 & 240 & 245 & 248 & 248 & 246 & 248 & 237 & 247 & 248 \\
\hline \multirow{3}{*}{ ADRS } & Pearson Corr. & $-.549 * *$ & 1 & $.540^{* *}$ & $.603^{* *}$ & $-.198^{* *}$ & $.721^{* *}$ & $.616^{* *}$ & $.746^{* *}$ & $.567^{* *}$ & $-.318^{* *}$ \\
\hline & Sig. (2-tailed) & .000 & & .000 & .000 & .002 & .000 & .000 & .000 & .000 & .000 \\
\hline & $\mathrm{N}$ & 240 & 240 & 240 & 240 & 240 & 240 & 240 & 237 & 240 & 240 \\
\hline \multirow{3}{*}{ ATGR } & Pearson Corr. & .091 & $.540^{* *}$ & 1 & $.631^{* *}$ & -.072 & .017 & $410^{* *}$ & $.693^{* *}$ & $.640^{* *}$ & -.038 \\
\hline & Sig. (2-tail) & .156 & .000 & & .000 & .265 & .795 & .000 & .000 & .000 & .549 \\
\hline & $\mathrm{N}$ & 245 & 240 & 245 & 245 & 245 & 245 & 245 & 237 & 245 & 245 \\
\hline \multirow{3}{*}{ ERNT } & Pearson Corr. & -.030 & $.603^{* *}$ & $.631^{* *}$ & 1 & $.126^{*}$ & $.300^{* *}$ & $421^{* *}$ & $.688^{* *}$ & $.714^{* *}$ & -.119 \\
\hline & Sig. (2-tailed) & .637 & .000 & .000 & & .047 & .000 & .000 & .000 & .000 & .060 \\
\hline & $\mathrm{N}$ & 248 & 240 & 245 & 250 & 250 & 246 & 250 & 237 & 247 & 249 \\
\hline \multirow{3}{*}{ HT } & Pearson Corr. & -.005 & $-.198^{* *}$ & -.072 & $.126^{*}$ & 1 & $-.306^{* *}$ & $-.711^{* *}$ & $-.198^{* *}$ & $.343^{* *}$ & $-.327^{* *}$ \\
\hline & Sig. (2-tailed) & .940 & .002 & .265 & .047 & & .000 & .000 & .002 & .000 & .000 \\
\hline & $\mathrm{N}$ & 248 & 240 & 245 & 250 & 250 & 246 & 250 & 237 & 247 & 249 \\
\hline \multirow{3}{*}{ INA } & Pearson Corr. & $-.717^{* *}$ & $.721^{* *}$ & .017 & $.300 * *$ & $-.306^{* *}$ & 1 & $.519 * *$ & $.523^{* *}$ & $.253^{* *}$ & $-.398^{* *}$ \\
\hline & Sig. (2-tailed) & .000 & .000 & .795 & .000 & .000 & & .000 & .000 & .000 & .000 \\
\hline & $\mathrm{N}$ & 246 & 240 & 245 & 246 & 246 & 246 & 246 & 237 & 246 & 246 \\
\hline \multirow{3}{*}{ KORF } & Pearson Corr. & -.088 & $.616^{* *}$ & $.410^{* *}$ & $.421^{* *}$ & $-.711^{* *}$ & $.519 * *$ & 1 & $.663^{* *}$ & $.171^{* *}$ & $.347^{* *}$ \\
\hline & Sig. (2-tailed) & .165 & .000 & .000 & .000 & .000 & .000 & & .000 & .007 & .000 \\
\hline & $\mathrm{N}$ & 248 & 240 & 245 & 250 & 250 & 246 & 250 & 237 & 247 & 249 \\
\hline \multirow{3}{*}{ LEDO } & Pearson Corr. & $-.155^{*}$ & $.746^{* *}$ & $.693^{*}$ & $.688^{*}$ & $-.198^{* *}$ & $.523^{* *}$ & $.663^{* *}$ & 1 & $.716^{* *}$ & $-.155^{*}$ \\
\hline & Sig. (2-tailed) & .017 & .000 & .000 & .000 & .002 & .000 & .000 & & .000 & .017 \\
\hline & $\mathrm{N}$ & 237 & 237 & 237 & 237 & 237 & 237 & 237 & 237 & 237 & 237 \\
\hline \multirow{3}{*}{ PODR } & Pearson Corr. & -.054 & $.567^{* *}$ & $.640^{* *}$ & $.714^{* *}$ & $.343^{* *}$ & $.253^{* *}$ & $.171^{* *}$ & $.716^{* *}$ & 1 & $-.358^{* *}$ \\
\hline & Sig. (2-tailed) & .402 & .000 & .000 & .000 & .000 & .000 & .007 & .000 & & .000 \\
\hline & $\mathrm{N}$ & 247 & 240 & 245 & 247 & 247 & 246 & 247 & 237 & 247 & 247 \\
\hline \multirow{3}{*}{ PTKM } & Pearson Corr. & $.632^{* *}$ & $-.318^{* *}$ & -.038 & -.119 & $-.327^{* *}$ & $-.398^{* *}$ & $347^{* *}$ & $-.155^{*}$ & $-.358^{* *}$ & 1 \\
\hline & Sig. (2-tailed) & .000 & .000 & .549 & .060 & .000 & .000 & .000 & .017 & .000 & \\
\hline & $\mathrm{N}$ & 248 & 240 & 245 & 249 & 249 & 246 & 249 & 237 & 247 & 249 \\
\hline
\end{tabular}

Note: $^{* *}$ - correlation significant at the 0.01 (2-tailed), *0.05

Source: Author's calculations

The correlation analysis of average prices of CROBEX10 stocks showed that the highest positive correlation, that is statistically significant at significance level of $1 \%$, is between ADRS-P-A and LEDO-R-A (0.746). On the other side, the highest negative correlation, that is statistically significant at $1 \%$, is between ADPL-R-A and INA-R-A (0.717). Also, the negative correlation between HT-R-A and KORF-R-A is remarkable high and statistically significant at significance level of $1 \%(-0.711)$. Those data a portfolio manager could use in order to manage its portfolio risk level.

Figure 4

Control Charts of PODR-R-A Stocks Average Prices Given in HRK in 2012, $k=247$ : (a) Control Chart for Individual Units (I); (b) Moving Range (MR) Control Chart; (c) 
Exponentially Weighted Moving Average (EWMA) Control Chart $(\lambda=0.3)$; (d) Cumulative Sum (CUSUM) Control Chart

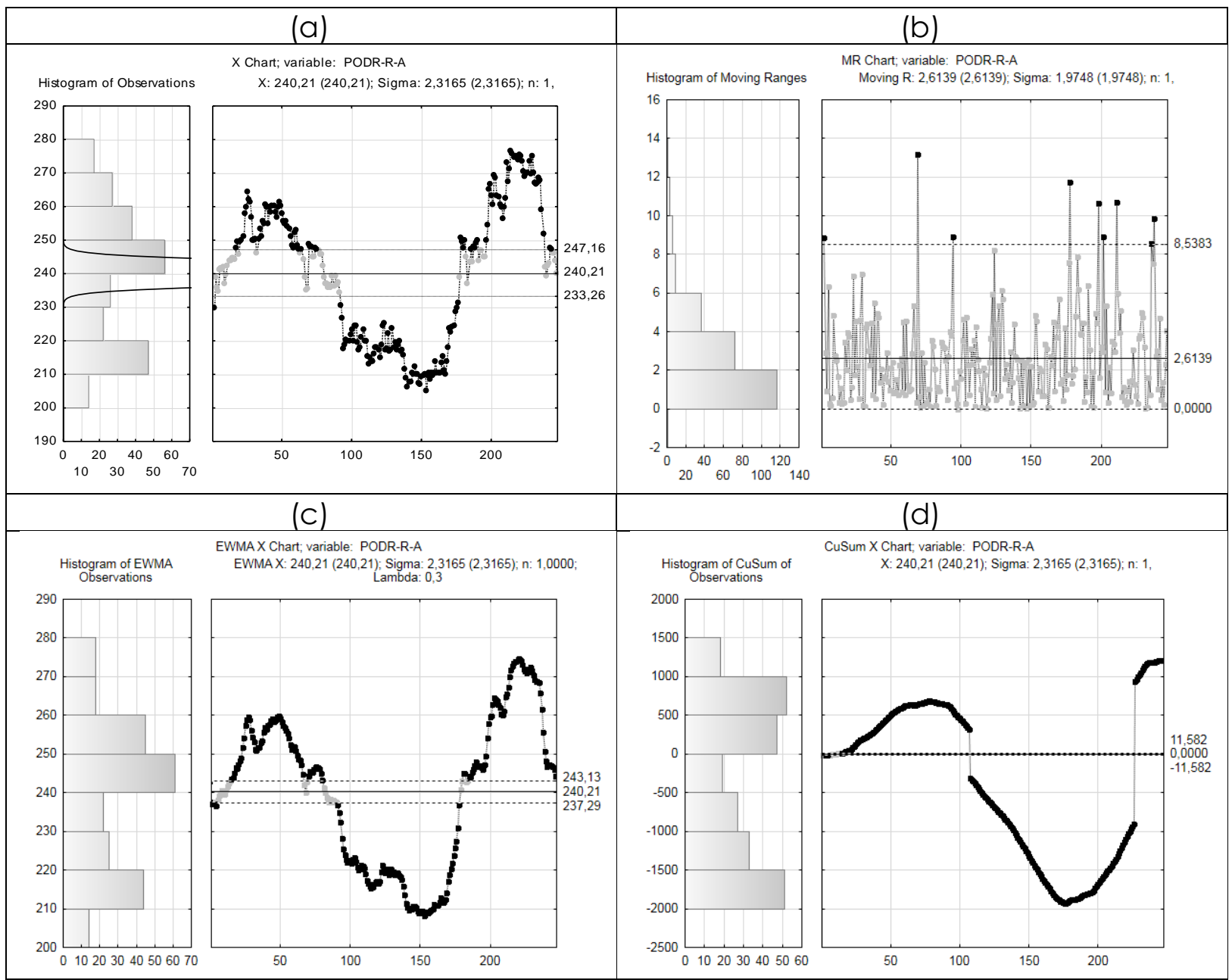

Source: Author's illustration

The I, EWMA and CUSUM control charts are made for PODR-R-A based on average stock prices and are given in Figure 4. Again, too many dots outside control limits make it impossible for an investor to make any decision whether to buy or sell stocks. The problem of false alarms, that conceal real signs to buy or sell stocks, is present at all CROBEX10 stocks. Because of that it can be concluded that stock average prices in combination with statistical control chart cannot be used in a portfolio analysis.

\section{Discussion}

The conducted analysis brought up a question why control charts showed so many false alarms which prevented them to be useful in a portfolio analysis. In order to answer this question the open and average stock prices were additionally examined. 
Table 6

Open and Average Prices Normality Tests and Autocorrelation Analysis of CROBEX10 Stocks, 2012

\begin{tabular}{|c|c|c|c|c|c|c|}
\hline \multirow{3}{*}{$\begin{array}{l}\text { CROBEX10 } \\
\text { stock }\end{array}$} & \multicolumn{3}{|c|}{ Open price } & \multicolumn{3}{|c|}{ Average price } \\
\hline & \multicolumn{2}{|c|}{ Normality test } & \multirow{2}{*}{$\begin{array}{l}\text { Autocorrelation } \\
\text { coefficient } \\
\text { (lag = 1) }\end{array}$} & \multicolumn{2}{|c|}{ Normality test } & \multirow{2}{*}{$\begin{array}{l}\text { Autocorrelation } \\
\text { coefficient } \\
\text { (lag = 1) }\end{array}$} \\
\hline & $\begin{array}{l}\text { Shapiro- } \\
\text { Wilks }\end{array}$ & $p$-value & & $\begin{array}{l}\text { Shapiro- } \\
\text { Wilks }\end{array}$ & $p$-value & \\
\hline ADPL-R-A & 0.9158 & 0.0000 & 0.9782 & 0.9126 & 0.0000 & 0.9837 \\
\hline ADRS-P-A & 0.8114 & 0.0000 & 0.9687 & 0.8058 & 0.0000 & 0.9771 \\
\hline ATGR-R-A & 0.9724 & 0.0001 & 0.9336 & 0.9711 & 0.0001 & 0.9524 \\
\hline ERNT-R-A & 0.9452 & 0.0000 & 0.9735 & 0.9453 & 0.0000 & 0.9753 \\
\hline HT-R-A & 0.8280 & 0.0000 & 0.9803 & 0.8288 & 0.0000 & 0.9800 \\
\hline INA-R-A & 0.8912 & 0.0000 & 0.9800 & 0.8916 & 0.0000 & 0.9861 \\
\hline KORF-R-A & 0.9203 & 0.0000 & 0.9762 & 0.9180 & 0.0000 & 0.9808 \\
\hline LEDO-R-A & 0.8783 & 0.0000 & 0.9696 & 0.8796 & 0.0000 & 0.9719 \\
\hline PODR-R-A & 0.9517 & 0.0000 & 0.9806 & 0.9500 & 0.0000 & 0.9836 \\
\hline PTKM-R-A & 0.9016 & 0.0000 & 0.9670 & 0.8989 & 0.0000 & 0.9758 \\
\hline
\end{tabular}

Source: Author's calculations

Two main assumptions of control chart are that the data points are normally distributed and that they are not autocorrelated (Montgomery, 2013). In Table 6 are provided results of normality tests and autocorrelation coefficients for CROBEX 10 stocks based on open and average prices from 2012. The results have shown that all stock prices are not normally distributed and that they have rather high autocorrelation coefficients. These two reasons could be the reasons why control chart showed to be useless in a portfolio analysis.

\section{Conclusion}

The paper studied the ability of statistical control charts to be used in the short-term stocks portfolio analysis. Under a short-term here is considered a year. Therefore, in the analysis data from Zagreb Stock Exchange in 2012 were used. In order to be sure that there are enough data points for quality analysis only CROBEX 10 stocks were observed. Among many different information variables about stocks, as the most important variables for an investor were evaluated open and average stock prices. So, these variables were used in the study.

Because of the variable characteristics, in the analysis emphasize was given on individual (I), exponentially weighted moving average (EWMA) and cumulative sum (CUSUM) control charts. The analysis has shown that the used control charts are not highly useful because of high rate of, possible false, alarms. Additional analysis showed that stock price data are non-normally distributed and autocorrelated. In the further research, possible approaches to dealing with this data flaws should be investigated, and then the possibility of statistical control charts use in a portfolio analysis should be considered again.

\section{References}

1. Almenberg, J., Dreber, A. (2012), "Gender, Stock Market Participation and Financial Literacy", SSE/EFI Working Paper Series in Economics and Finance, No. 737, available at http://swopec.hhs.se/hastef/papers/hastef0737.pdf (29 September 2014). 
2. Benić V., Franić, I. (2008), "Stock Market Liquidity: Comparative Analysis of Croatian and Regional Markets", Financial Theory and Practice, Vol. 32 No. 4, pp. 477-498.

3. Bogan, V. (2008), "Stock Market Participation and the Internet", Journal of Financial and Quantitative Analysis, Vol. 43 No. 1, pp. 191-212.

4. Box, G. E. P., Luceno, A., Paniagua-Quinones, M. D. C., (2009), "Statistical Control by Monitoring and Adjustment", $2^{\text {nd }}$ ed., New Jersey, John Wiley \& Sons.

5. Caporale, G. M., Howells, P. G. A, Soliman, A. M. (2004), "Stock market development and economic growth: The causal linkage", Journal of Economic Development, Vol. 29 No. 1, pp. 33-50.

6. Chen, T. (2010), "On reducing false alarms in multivariate statistical process control", Chemical Engineering Research and Design, Vol. 88 No. 4, pp. 430-436.

7. del Castillo, E. (2002), "Statistical Process Adjustment for Quality Control", New York, John Wiley \& Sons.

8. Dumičić, K., Žmuk, B. (2011a), "Metode statističke kontrole kvalitete" ("Statistical Quality Control Methods"), in Dumičić, K., Bahovec, V. (Eds.), Poslovna statistika (Business Statistics), Zagreb, Element, pp. 459-539.

9. Dumičić, K., Žmuk, B. (2011b), "Monitoring delivery time with control charts", in Katalinić. B. (Ed.), Annals of DAAAM for 2011 \& Proceedings of the 22nd DAAAM International World Symposium, Vienna, Austria, November 24-26, 2011, Vienna, DAAAM International Vienna, pp. 1199-1200.

10. Gandy, A. (2012), "Performance monitoring of credit portfolios using survival analysis", International Journal of Forecasting, Vol. 28 No. 1, pp. 139-144.

11. Guiso, L., Sapienza, P., Zingales, L., (2008), "Trusting the Stock Market", The Journal of Finance, Vol. 63 No. 6, pp. 2557-2600.

12. Hong, H., Kubik, J. D., Stein, J. C. (2004), "Social Interaction and Stock-Market Participation", The Journal of Finance, Vol. 59 No. 1, pp. 137-163.

13. Hunter, J. S. (1986), "The Exponentially Weighted Moving Average", Journal of Quality Technology, Vol. 18 No. 4, pp. 203-210.

14. Liu, C. S., Tien, F. C. (2011), "An Evaluation of Single-Featured EWMA-X (SFEWMAX) Control Chart with Process Mean Shifts and Standard Deviation Changes", International Journal of Applied Science and Engineering, Vol. 9 No. 2, pp. 111 121.

15. Manas, A. T. (2005), "The increasing relevance of the stock market in the world: A new scenario", available at http://www2.uah.es/iaes/publicaciones/DT_01_05.pdf (29 September 2014).

16. McNeese, W., Wilson, W. (2002), "Using time series charts to analyse financial data", available at http://www.spcforexcel.com/files/timeseriesfinancial.pdf (30 September 2014).

17. Montgomery, D. C, Friedman, D. J. (1989), "Statistical process control in computer integrated manufacturing environment", in Keats, J. B., Hubele, N. F. (Eds.), Statistical Process Control in Automated Manufacturing, New York, Marcel Dekker, pp. 67-88.

18. Montgomery, D. C. (2013), "Statistical Quality Control: A Modern Introduction", $7^{\text {th }}$ ed., Singapore, John Wiley \& Sons.

19. Montgomery, D. C., Jennings, C. L., Pfund, M. E. (2011 a), "Managing, Controlling, and Improving Quality", New Jersey, John Wiley \& Sons.

20. Montgomery, D. C., Runger, G. C. (2011 b), "Applied Statistics and Probability for Engineers", New Jersey, John Wiley \& Sons.

21. Page, E. S. (1954), "Continuous Inspection Scheme", Biometrika, Vol. 41 No. 1-2, pp. 100-115. 
22. Rebisz, B. (2014), "Appliance of Quality Control Charts for Sovereign Risk Modelling", available at http://iriaf.univ-poitiers.fr/images/medias/fichier/v-s3-4rebisz_1402061581460-pdf (30 September 2014).

23. Riaz, M., Abbas, N., Does, R. J. M. M. (2011), "Improving the Performance of CUSUM Charts", Quality and Reliability Engineering International, Vol. 27 No. 4, pp. 415-424.

24. Roberts, S. W. (1959), "Control Chart Tests based on Geometric Moving Averages", Technometrics, Vol. 1 No. 3, pp. 239-250.

25. Ryu, J. H., Wan, H., Kim, S. (2010), "Optimal Design of a CUSUM Chart for a Mean Shift of Unknown Size", Journal of Quality Technology, Vol. 42 No. 3, pp. 311-326.

26. SAS Institute (2014), "Statistical Details for CUSUM Control Charts", available at http://www.jmp.com/support/help/Statistical_Details_for_CUSUM_Control_Charts. shtml (3 October 2014).

27. Tachiwou, A. M. (2010), "Stock Market Development and Economic Growth: The Case of West African Monetary Union", International Journal of Economics and Finance, Vol. 2 No. 3, pp. 97-103.

28. van Rooij, M., Lusardi, A., Alessie, R. (2011), "Financial literacy and stock market participation", Journal of Financial Economics, Vol. 101 No. 2, pp. 449-472.

29. Wild, C. J., Seber, G. A. F. (1999), "Chance Encounters: A First Course in Data Analysis and Inference", New York, John Wiley \& Sons.

30. Zagreb Stock Exchange (2014a), "2013 Trading Summary", available at http://zse.hr/UserDocslmages/reports/ZSE-2013-eng.pdf (1 October 2014).

31. Zagreb Stock Exchange (2014b), "Historical Overview", available at http://zse.hr/default.aspx?id=32877 (1 October 2014).

32. Zagreb Stock Exchange (2014c), "Index CROBEX10", available at http://zse.hr/default.aspx?id=44102\&index=CROBEX10 (1 October 2014).

33. Zagreb Stock Exchange (2014d), "Indices", available at http://zse.hr/default.aspx?id=43539 (1 October 2014).

\section{About the authors}

Ksenija Dumičić is a Full Professor with Tenure at the Department of Statistics, Faculty of Economics \& Business, University of Zagreb. Her main research fields include sampling, statistics, business statistics, sampling for social and business surveys. The author can be contacted at kdumicic@efzg.hr

Berislav Žmuk is a Senior Assistant at the Department of Statistics, Faculty of Economics \& Business, University of Zagreb. His main research fields include applications of statistics in business and economy, sampling and statistical quality analysis. The author can be contacted at bzmuk@efzg.hr 